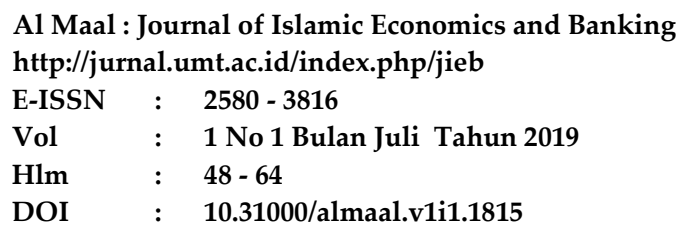

\title{
Pengaruh Label Halal Terhadap Produk Kecantikan
}

\author{
Ananya Larasati1, ${ }^{1,}$, Ikhwan Hamdani ${ }^{2}$, Santi Lisnawati ${ }^{3}$ \\ ${ }^{123}$ Universitas Ibn Khaldun Bogor, Indonesia \\ *Email : ananyalarasati89@gmail.com
}

\begin{abstract}
The purpose of this study is how to use halal labels on decisions purchase of Muslim beauty products in Bogor. Thiis study uses quantitative research methods. The data sources used are primary and secondary data. The respondents who were sampled in this study were 100 people. The process of data analysis in this study uses simple linear regression analysis. Significant halal variable labels on purchasing decisions this is seen from the halal significant label of 0,000 which means it is smaller than the significance level used which is 0.05 . And it can also be seen from $t$ count of 5.110 which means that the t count is greater than t table which is 1.984. The decision to buy Muslims is based on the label of halal presence on product packaging, the selection of products labeled halal is based on the beliefs and attitudes of Muslim women to buy products labeled halal.
\end{abstract}

Keyword: Beauty; Buying decision; Halal; Label; Product

\section{ABSTRAK}

Tujuan dari penelitian ini untuk mengetahui bagaimana pengaruh label halal terhadap keputusan pembelian produk kecantikan muslimah di Bogor. Penelitian ini menggunakan metode penelitian kuantitatif. Sumber data yang digunakan adalah data primer dan skunder. Responden yang dijadikan sampel dalam penilitian ini sebanyak 100 orang. Proses analisis data dalam penelitian ini menggunakan analisis regresi linier sederhana. Variabel label halal berpengaruh secara signifikan terhadap keputusan pembelian hal ini dilihat dari signifikan label halal sebesar 0,000 yang berarti lebih kecil dari tingkat signifikansi yang digunakan yaitu 0,05. Dan dapat juga dilihat dari t hitung sebesar 5.110 yang berarti thitung lebih besar dari t tabel yaitu 1.984. Keputusan pembelian para muslimah didasarkan dengan adanya label halal pada kemasan produk, pemilihan produk berlabel halal didasarkan pada keyakinan dan sikap para muslimah untuk membeli produk berlabel halal.

Kata kunci: Halal; Kecantikan; Keputusan pembelian; Label; Produk 


\section{Pendahuluan}

Berdasarkan survei penduduk antar sensus (Supas) 2015 jumlah penduduk Indonesia pada 2019 diproyeksikan mencapai 266,91 juta jiwa. Menurut jenis kelamin, jumlah tersebut terdiri atas 134 juta jiwa laki-laki dan 132,89 juta jiwa perempuan.

Perempuan merupakan segmentasi pasar yang potensial dan memiliki banyak kebutuhan. Setiap harinya, perempuan tidak bisa terlepas dari penggunaan produk kecantikan. Oleh karena itu, banyak perusahaan yang berusaha memenuhi kebutuhan akan kecantikan dengan berbagai macam inovasi produk, inovasi produk kecantikan dilakukan oleh produsen untuk memperoleh kepercayaan konsumen terhadap produk seiring banyak beredarnya produk kecantikan/make-up palsu di pasaran.

Di samping itu, mayoritas penduduk di Indonesia adalah muslim, maka dari itu kepastian tentang kehalalan produk merupakan hal yang penting untuk diperhatikan. Dalam upaya pemenuhan kebutuhannya, seseorang akan memilih produk yang dapat memberikan kepuasan tertinggi. Kepuasan tertinggi dapat dirasakan tidak hanya secara lahir saja namun juga secara batin (Utami, 2013).

Dalam buku New Wave Marketing-nya Kertajaya (2008), dipaparkan ada 3 new wave ready costumer (target pasar potensial baru). Target pasar potensial pertama adalah kaum muda. Kedua, perempuan dan ketiga netizen (pengguna internet).

Pembahasan penelitian fokus pada konsumen perempuan. Konsumen golongan ini adalah konsumen yang kuat dalam dunia pemasaran. Ada 3 (tiga) hal mengapa perempuan sangat penting dalam pemasaran. Pertama, mereka adalah konsumen berpengaruh. Faktanya, 97\% pembelian dipengaruhi oleh perempuan. Keperluan kantor, belanja rumah, secara rata-rata dipengaruhi oleh perempuan. Kaum pria membeli peralatan rumah tetapi keputusannya dipengaruhi oleh perempuan. Kemudian kaum pria membeli fashion, parfum, jam tangan semua dilakukan untuk tampil sempurna di depan perempuan. Kedua, kekuatan perempuan dilanskap bisnis semakin kuat. Dari waktu ke waktu jumlah perempuan yang bekerja semakin banyak. Tidak hanya pada sektor industri, pada bidang politik-pun sekarang banyak perempuan yang sudah terjun. Dan sampai sekarang, angka perempuan yang bekerja diperkirakan mencapai satu miliar di seluruh dunia. Ketiga, perempuan konsumtif tapi teliti. Secara umum perempuan lebih konsumtif dibanding pria tetapi mereka lebih bisa membelanjakan uangnya pada hal-hal yang lebih berguna.

Menurut survey website Republika, perempuan juga dinilai merupakan sasaran empuk bagi bisnis e-commerce atau online marketplace di Indonesia. Kebiasaan wanita yang gemar berbelanja dan merekomendasi barang ke teman atau saudara dimanfaatkan oleh sebuah e-commerce.

Berhubung dengan banyaknya umat Muslim di Indonesia, yang memiliki selera dan kebiasaan mengkonsumsi dan menggunakan produk halal, label halal pun mulai banyak disematkan pada suatu produk. Label halal dapat disematkan apabila sudah melalui prosedur sertifikasi halal MUI.

Sesuai dengan tugasnya, MUI membantu pemerintah dalam melakukan hal-hal yang menyangkut kemaslahatan umat Islam, seperti mengeluarkan fatwa dalam kehalalan sebuah makanan, penentuan kebenaran sebuah aliran dalam agama Islam, dan hal-hal yang berkaitan dengan hubungan seorang muslim dengan lingkungannya. LPPOM MUI (Lembaga Pengkajian Pangan, Obat-obatan, dan Kosmetika Majelis Ulama Indonesia) 
adalah lembaga yang bertugas kuat untuk meneliti, mengkaji, menganalisa dan memutuskan apakah produk-produk baik pangan dan turunannya, obat-obatan dan produk kosmetika apakah aman dikonsumsi baik dari sisi kesehatan dan dari sisi pengajaran agama Islam yakni halal atau boleh dan baik untuk dikonsumsi bagi umat muslim khususnya di wilayah Indonesia, selain itu memberikan rekomendasi, merumuskan ketentuan dan bimbingan kepada layanan masyarakat.

Menurut Rafita (2017:65) Kebutuhan akan jaminan halal pada produk kecantikan menjadi penting khususnya di Indonesia. Maka dari itu kepastian tentang kehalalan produk merupakan hal yang penting untuk diperhatikan. Hal ini dikarenakan umat muslim dilarang mengkonsumsi produk-produk yang mengandung bahan-bahan yang tidak halal. Label halal yang terdapat pada kemasan produk, akan mempermudah konsumen dalam mengidentifikasi produk. Di Indonesia penggunaan label halal sangat mudah ditemukan, pada produk kecantikan salah satunya. Pemberian label halal pada produk, sedikit banyak akan mengurangi keraguan konsumen akan kehalalan produk yang dibeli. Terutama pada konsumen wanita yang setiap harinya selalu mengkonsumsi produk kecantikan untuk menambah rasa percaya diri dalam berpenampilan. Hal tersebut dikarenakan produk kecantikan yang dinyatakan halal cenderung lebih aman dan terhindar dari kandungan zat berbahaya.

Menurut penelitian yang dilakukan oleh Asriah (2013) bahwa ada pengaruh secara positif dan signifikan antara pencantuman label halal dengan perilaku pembelian masyarakat. Menurut penelitian yang dilakukan oleh Widodo (2015) hasil penelitian menunjukkan bahwa labelisasi halal dan harga adalah faktor yang paling penting mempengaruhi keputusan pembelian konsumen. Peneltian yang dilakukan oleh Yasnita (2015) menunjukkan bahwa tidak terdapat hubungan yang signifikan namun memiliki hubungan yang positif antara label halal terhadap minat beli. Hasil analisis menunjukkan bahwa label halal berada pada persentase 55\% dengan kategori rendah, dan minat beli diperoleh persentase sebesar $81 \%$ dengan kategori tinggi. Adapun penelitian ini bertujuan untuk mengetahui pengaruh label halal terhadap keputusan pembelian produk kecantikan bagi para muslimah di Kotamadya Bogor.

\section{KAJIAN LITERATUR Produk Halal}

Rafita (2017) mengatakan bahwa produk adalah barang atau jasa yang dibuat dan ditambah gunanya atau nilainya dalam proses produksi dan menjadi hasil akhir dari proses produksi.

Menurut Kotler dan Amstrong dalam Rahman (2010) produk adalah segala sesuatu yang ditawarkan ke pasar untuk mendapatkan perhatian, dibeli, dipergunakan dan dapat memuaskan atau memenuhi kebutuhan konsumen.

Menurut Eldnie (2013) produk adalah setiap hal yang diterima orang dalam suatu pertukaran mencakup semua atribut yang tak terukur dan terukur dan diharapkan manfaatnya.

Kotler mendefinisikan produk sebagai segala sesuatu yang dapat ditawarkan pada pasar untuk memenuhi keinginan dan kebutuhan namun jika ditinjau dari perspektif Islam, Syariah Islam memiliki batasan tertentu yang lebih spesifik mengenai definisi 
produk. Dalam syariah Islam ada enam hal yang perlu dipenuhi ketika kita menawarkan sebuah produk, yaitu:

a) Produk yang dijual dibutuhkan oleh semua orang.

b) Produk yang ditawarkan memiliki kejelasan barang kejelasan ukuran atau takaran kejelasan komposisi dan menggunakan bahan yang baik.

c) Produk yang dijual tidak rusak dan cacat.

d) Produk diperjualbelikan adalah produk yang halal.

e) Produk yang dijual tidak mengandung boraks dan penipuan.

f) Produk yang dijual tidak mencampur antara kualitas yang rendah dengan yang baik.

Dalam sebuah hadits Rasulullah disebutkan bahwa yang artinya: "jika barang itu rusak, katakanlah rusak, jangan engkau sembunyikan. Jika barang itu murah, jangan kau katakan mahal. Jika barang ini jelek katakanlah jelek, jangan kau katakan bagus". (HR Tirmidzi).

Hadis tersebut juga didukung HR Ibnu Majah dan Ibnu Hambal, "Tidak dihalalkan bagi seorang muslim menjual barang yang cacat kecuali ia memberitahukannya."

Uraian di atas jelas mengatakan bahwa hukum menjual produk cacat yang disembunyikan adalah haram. Artinya produk meliputi barang dan jasa yang ditawarkan kepada konsumen harus berkualitas sesuai dengan yang dijanjikan. Persyaratan mutlak yang juga harus ada di dalam sebuah produk adalah harus memenuhi kriteria halal (Hamdi, 2017).

Konsep halal dalam kehidupan masyarakat Indonesia telah banyak dikenal dan diterapkan. Halal diperuntukkan bagi segala sesuatu yang baik dan bersih dimakan atau dikonsumsi oleh manusia sesuai menurut syariat Islam. Lawan halal adalah haram yang berarti "tidak dibenarkan atau dilarang" menurut syariat Islam. Dalam Q.S An Nahl: 114 Allah telah memerintahkan kepada manusia untuk hanya memakan (mengkonsumsi) makanan halal. Jika diterapkan dalam konteks sekarang, ayat tersebut berlaku tidak terbatas hanya pada makanan, tetapi juga pada produk-produk lain yang bisa dikonsumsi manusia, termasuk produk kecantikan (Rafita, 2017).

Burhan (2017) mengatakan bahwa produk halal adalah produk pangan, obat, kosmetika dan produk lain yang tidak mengandung unsur atau barang haram dalam proses pembuatannya serta dilarang untuk dikonsumsi umat Islam baik yang menyangkut bahan baku, bahan tambahan, bahan pembantu lainnya termasuk bahan produksi yang diolah melalui proses rekayasa genetika dan iradasi yang pengolahannya dilakukan sesuai dengan syariat Islam serta memberikan manfaat yang lebih daripada mudharat (Nurlaili, 2014).

Utami (2013) mengatakan bahwa produk kosmetik memang tidak dimakan dan masuk ke dalam tubuh. Oleh karena itu kosmetik biasanya dikaitkan dengan masalah suci atau najis. Produk tersebut bisa dikatakan haram jika produk kosmetik tersebut mengandung bahan-bahan najis. Produk kosmetik halal atau haram memiliki perbedaan dalam hal kandungan, adapun beberapa unsur yang tidak boleh terkandung dalam produk kosmetik diantaranya unsur hewan najis sperti babi, hewan puas, bangkai, unsur tubuh 
manusia, darah, khamar, dan hewan halal seperti sapi yang disembelih secara tidak syar'i selain itu seperti turunan hewan (kolagen) atau pun bagian dari tubuh manusia, misalnya plasenta.

\section{Merk, Kemasan dan Labeling}

Eldine (2013) menyatakan bahwa terdapat tiga hal-hal penting dari suatu produk yaitu (dan terutama sekali suatu produk konsumen) mengenai merek, pembungkus, dan labelnya. Mereka mungkin digunakan untuk mengidentifikasi produk dengan suatu produk sukses atau untuk mencirinya dari produk lain. Mereka dirancang untuk menarik pelanggan atau untuk menyediakan informasi ke pembeli potensial. Sebab merek, paket, dan label adalah sesuatu yang sangat riil bagian dari produk mereka direncanakan yang dirancang secara hati-hati agar dapat menarik perhatian konsumen. Suatu merek adalah suatu nama, istilah, lambang, desain atau manapun semua kombinasi yang mengidentifikasikan suatu penjualan produk dan menciri mereka dari produk pesaing. Suatu merek dagang adalah suatu bagian dari merek yang disebutkan. Meliputi surat, kata-kata, angka-angka dan lambang yang dapat diucapkan. Suatu tanda merek, pada sisi lain, adalah bagian dari merek yang merupakan suatu lambang atau desain yang membedakannya.

Produk yang sudah jadi masih memerlukan proses selanjutnya proses ini disebut pengemasan pengemasan sendiri merupakan elemen penting dalam membangun merek (Kurniawan, 2018). Menurut Kotler dan Keller dalam Rahman (2010) pengemasan adalah sebuah kegiatan merancang dan memproduksi wadah untuk produksi. Kemasan sendiri harus memiliki sifat-sifat komersial agar dapat digunakan dengan baik, antara lain: harus dapat mewadahi produk, harus dapat melindungi produk, dan harus dapat menjual produk.

Banyak cara dilakukan dalam upaya pemilihan produk yang sesuai dengan kebutuhan. Salah satunya dengan mencari informasi yang terdapat pada atribut produk. Pengembangan suatu produk melibatkan pendefinisian manfaat yang akan ditawarkan produk tersebut. Manfaat ini dikomunikasikan dan dihantarkan oleh atribut produk. Atribut produk menjadi unsur- unsur yang dipandang penting oleh konsumen dan dijadikan dasar dalam pengambilan keputusan membeli. Melalui atribut produk konsumen dapat memperoleh jawaban apakah produk. yang akan dibeli sudah sesuai dengan kebutuhan dan keinginan sehingga memperoleh kepuasan secara lahir dan batin. Atribut yang dimaksud sebagai media informasi konsumen untuk memperoleh kepercayaan terhadap produk secara lahir batin adalah label halal. Label adalah etiket merek dagang, dengan keterangan tentang mutu produk yang dicantumkan pada produk atau kemasan. (Rafita, 2017).

Menurut Eldine (2013) label adalah presentasi informasi pada suatu produk atau paketnya. Label adalah bagian yang berisi informasi. Mungkin meliputi merek dagang dan tanda dan merek dagang lambang yang dicatatkan, klaim produk (muatan/indeks) dan ukuran paket, nama dan alamat dari pabrikan, dan lambang kode produk yang universal, yang digunakan untuk gerbang keluar dan pengendalian persediaan yang diotomatkan.

Label berbeda dengan kemasan. Label harus yang sederhana, mudah diingat oleh konsumen. Label sendiri harus menyertakan informasi-informasi tambahan dalam suatu produk. Beberapa instansi dan lembaga pemerintahan sangat peduli pada pelabelan ini, Badan Pengawas Obat dan Makanan (BPOM) meminta semua produk untuk memberikan masa kadaluarsa pada kemasan dan menyatakan kandungan dan komposisi gizi sebuah 
produk. Di Indonesia, semua produk harus menyertakan sertifikasi berupa label halal dari MUI (Majelis Ulama Indonesia) tujuannya adalah agar produk tersebut aman dikonsumsi oleh konsumen (Kurniawan, 2018).

\section{Sertifikasi Halal}

Menurut Johan (2018) Muslim sangat selektif dalam memilih dan membeli makanan dan produk lainnya di pasar. Mereka tidak akan membeli barang atau produk yang diragukan. Sertifikasi halal telah menjadi sesuatu yang sangat penting untuk memenuhi perusahaan. Hukum pelabelan nasional dan logo harus mencari keseimbangan antara persyaratan pelabelan dan sertifikasi untuk meminimalkan hambatan perdagangan bebas. Agama memiliki pengaruh di masyarakat Indonesia. Mereka hanya ingin mengkonsumsi dan menggunakan produk dengan tanda-tanda jaminan halal resmi yang dikeluarkan oleh pemerintah. Di satu sisi, fenomena tersebut menunjukkan tingkat kesadaran tentang pelaksanaan keyakinan berdasarkan hukum Islam, di sisi lain mendorong sensitivitas mereka ketika makanan atau produk lainnya bersentuhan dengan unsur-unsur haram dan halal. Produk halal lalu mendapatkan pengakuan di seluruh dunia sebagai patokan baru untuk keamanan dan jaminan kualitas. Produk yang diproduksi dengan sertifikasi halal yang mudah diterima oleh konsumen Muslim serta konsumen dari agama-agama lain. Penerimaan ini disebabkan konsep kebajikan dari halal, yang tidak hanya mencakup kebutuhan Syariah tetapi juga aspek kebersihan, sanitasi dan keselamatan. Untuk memastikan kehalalan kepada konsumen, standar halal memperkenalkan ke industri halal serta sertifikasi halal dari organisasi Islam terpercaya. Sertifikasi halal di Indonesia ditangani oleh beberapa lembaga. Badan Pengawasan Obat dan Makanan (BPOM) untuk produk makanan kemasan. Sementara itu, sertifikat halal yang dikeluarkan oleh Majelis Ulama Indonesia (MUI) berdasarkan penilaian yang dilakukan oleh Lembaga Pengkajian Pangan, Obat-obatan, dan Kosmetika Majelis Ulama Indonesia (LPPOM MUI).

\section{Keputusan Pembelian}

Menurut Sunyoto (2018) setiap keputusan membeli mempunyai suatu struktur sebanyak tujuh, komponen-komponen tersebut adalah:

a) Keputusan tentang jenis produk. Konsumen dapat mengambil keputusan untuk membeli sebuah produk.

b) Keputusan tentang bentuk produk. Keputusan ini menyangkut ukuran mutu corak dan sebagainya.

c) Keputusan tentang merek. Konsumen harus mengambil keputusan tentang merek mana yang akan dibeli. Setiap merek memiliki perbedaan-perbedaan tersendiri.

d) Keputusan tentang penjualnya. Konsumen harus mengambil keputusan di mana produk tersebut akan dibeli.

e) Keputusan tentang jumlah produk. Konsumen dapat mengambil keputusan tentang seberapa banyak produk yang akan dibelinya pada suatu saat.

f) Keputusan tentang waktu pembelian. Konsumen dapat mengambil keputusan tentang kapan ia harus melakukan pembelian. Masalah ini akan menyangkut adanya uang. Oleh karena itu harus mengetahui faktor-faktor yang mempengaruhi keputusan konsumen dalam penentuan waktu pembelian. 
g) Keputusan tentang cara pembayaran. Konsumen harus mengambil keputusan tentang metode atau cara pembayaran produk yang akan dibeli. Keputusan tersebut akan mempengaruhi keputusan tentang penjual dan jumlah pembeliannya.

Tanarto (2013) mengatakan bahwa secara umum ada lima alasan dan motif utama yang menyebabkan seseorang melakukan pembelian.

a) Mendapat keuntungan. Artinya membeli produk dan jasa karena mendapat keuntungan lebih besar dari nilai uang yang dikeluarkan.

b) Mengikuti orang banyak. Artinya membeli produk dan jasa hanya karena mengikuti trend tanpa tahu manfaat dan kegunaannya.

c) Berhubungan dengan persoalan kehidupan. Artinya membeli produk dan jasa karena kondisi kesehatan, solusi karir, usaha perawatan, atau perbaikan. Hal ini mutlak dilakukan pembeli jika mereka tidak memenuhinya maka akan ada masalah teknis dan emosional dengan dirinya.

d) Rasa kebanggaan dan status. Artinya membeli produk dan jasa karena kebanggaan dan untuk meningkatkan citra diri.

e) Kesanggupan dan keputusan membayar. Artinya mempunyai dana atau penghasilan yang cukup untuk membeli produk dan jasa yang ditawarkan sekaligus sebagai pihak yang menentukan dalam mengambil keputusan mengenai transaksi tersebut.

Di sebagian besar negara-negara Muslim atau negara dengan mayoritas Muslim, standar halal memiliki bagian penting dalam melindungi hak-hak konsumen. Konsumen Muslim memiliki pengetahuan yang cukup tentang apa itu produk halal, setidaknya dengan mencari label halal pada kemasan produk. Pelabelan bertujuan untuk mengatur kepentingan yang berbeda yang berkisar dari kesehatan manusia, agama dan hak-hak konsumen untuk perdagangan internasional. Label halal memiliki porsi yang signifikan dalam pembelian Muslim (Johan, 2018).

\section{Metode Penelitian \\ Pendekatan Penelitian}

Penelitian ini menggunakan pendekatan kuantitatif. Karena permasalahan penelitian sudah jelas dan peneliti ingin mendapatkan informasi yang lebih luas dan nyata. Penelitian ini adalah penelitian tentang pengaruh label halal terhadap keputusan pembelian produk kecantikan .Disebut penelitian kuantitatif dikarenakan data penelitian berupa angka-angka dan analisis menggunakan statistik.

\section{Tempat Waktu Penelitian}

Penelitian ini akan menggunakan kuesioner dan akan dilakukan melalui Google Form. Google Form.Penggunaan Google Form ini bertujuan untuk menghemat kertas ( $g o$ green/ paperless culture), meminimalisir kehilangan data, dan dapat menjangkau responden di wilayah yang jauh. Waktu penelitian mulai dilaksanakan pada tahun 2019 sampai tercukupinya jumlah responden yaitu berjumlah 100 orang responden. 


\section{Definisi Operasional dan Pengukuran Variabel Penelitian}

Tabel 1 Definisi Operasional dan Pengukuran Variabel Penelitian

\begin{tabular}{|c|c|c|c|}
\hline Variabel & $\begin{array}{c}\text { Definisi Operasional } \\
\text { Variabel }\end{array}$ & Indikator & Pertanyaan \\
\hline \multirow{24}{*}{$\begin{array}{l}\text { Label Halal } \\
\qquad(X)\end{array}$} & \multirow{3}{*}{$\begin{array}{c}\text { Label halal adalah label } \\
\text { yang memuat keterangan } \\
\text { halal dengan standar }\end{array}$} & \multirow{4}{*}{ Label } & $\begin{array}{c}\text { Saya tahu maksud dari } \\
\text { label halal. }\end{array}$ \\
\hline & & & $\begin{array}{c}\text { Saya selalu } \\
\text { memperhatikan ada }\end{array}$ \\
\hline & & & tidaknya label halal \\
\hline & halal menurut Islam & & pada kemasan. \\
\hline & pada produk. Unsur & \multirow{9}{*}{ Tulisan } & Tulisan "halal" terbaca \\
\hline & yang tidak boleh & & dengan jelas. \\
\hline & terkandung di dalam & & Adanya tulisan "halal" \\
\hline & produk kecantikan, yaitu & & yang terdapat pada \\
\hline & diantaranya unsur & & gambar membantu saya \\
\hline & hewan najis, hewan & & mengidentifikasi produk. \\
\hline & buas, bangkai, unsur & & Saya mengetahui \\
\hline & tubuh manusia, & & gabungan gambar dan \\
\hline & darah,dan khamar. & & tulisan di samping \\
\hline & & \multirow{8}{*}{$\begin{array}{c}\text { Gambar dan } \\
\text { tulisan }\end{array}$} & $\begin{array}{c}\text { adalah label halal resmi } \\
\text { dari MUI. }\end{array}$ \\
\hline & & & Adanya label halal \\
\hline & & & menjadi pertimbangan \\
\hline & & & saya dalam memilih \\
\hline & & & produk kecantikan. \\
\hline & & & Saya mengetahui \\
\hline & & & dengan jelas letak label \\
\hline & & & halal pada kemasan \\
\hline & & \multirow{3}{*}{ Kemasan } & produk kecantikan. \\
\hline & & & Label halal \\
\hline & & & $\begin{array}{c}\text { mempermudah saya } \\
\text { untuk lebih yakin akan }\end{array}$ \\
\hline
\end{tabular}




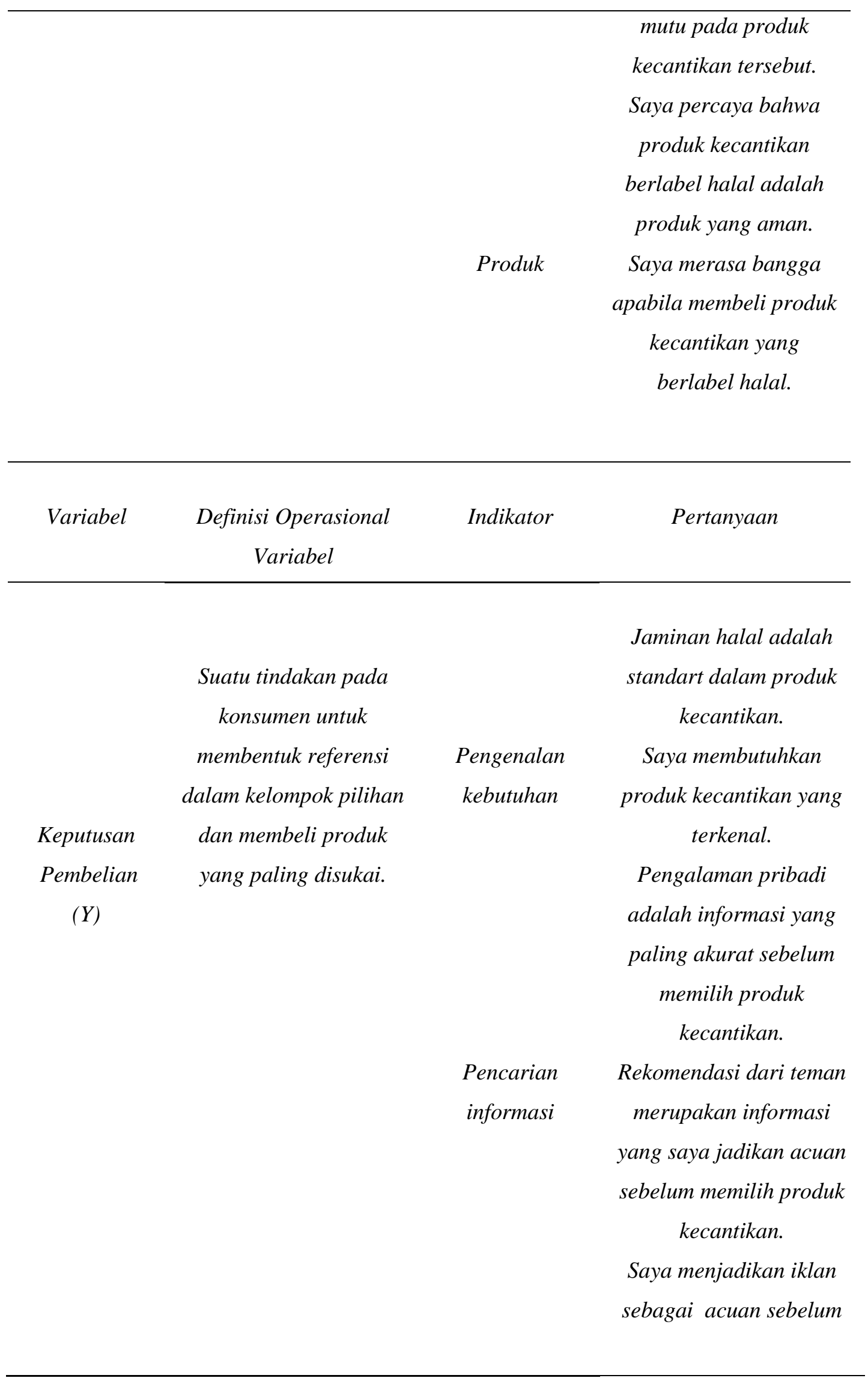




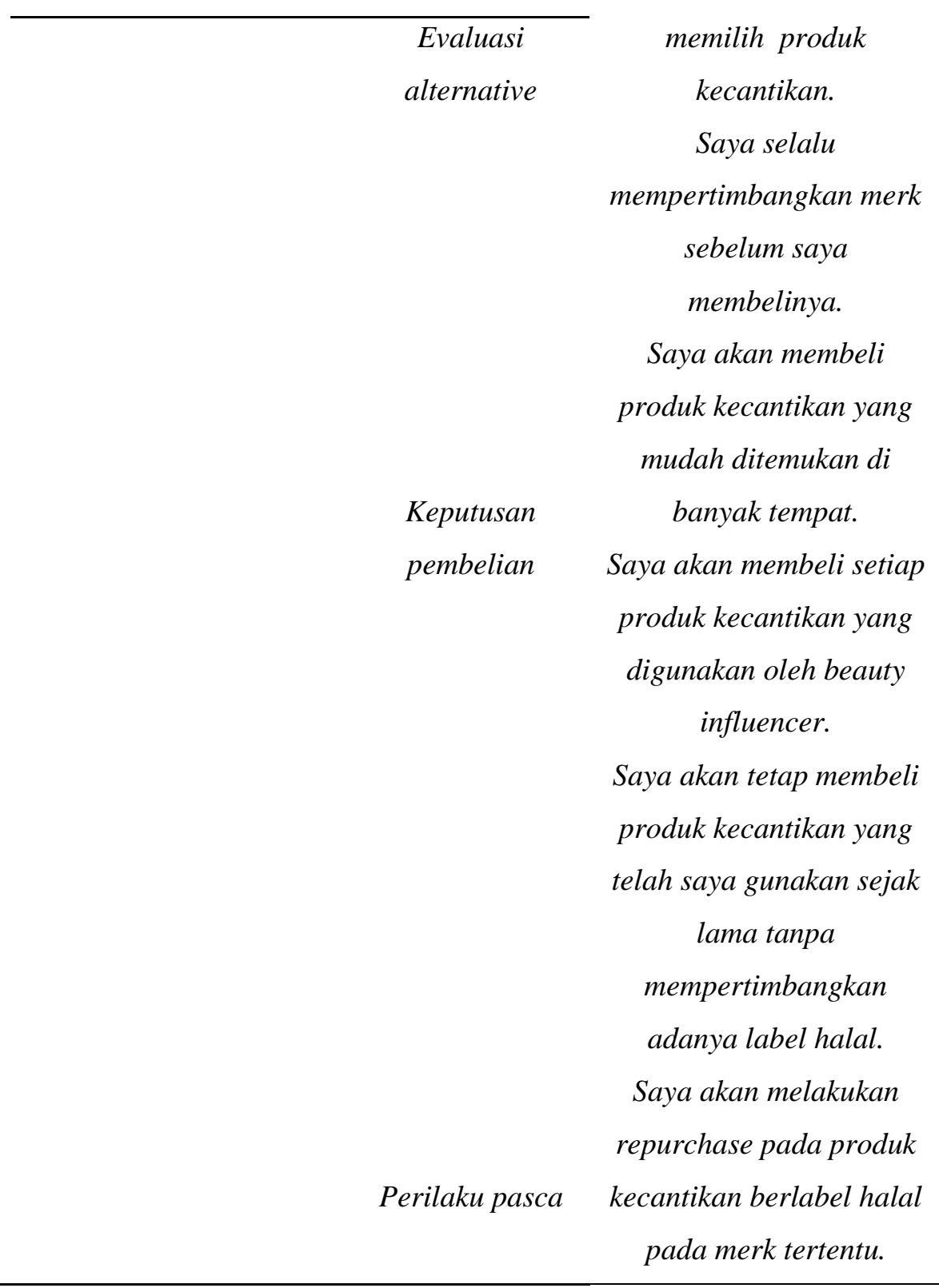

\section{Populasi dan Sampel}

Pengertian populasi menurut Sunyoto (2012) adalah jumlah dari keseluruhan objek satuan atau individu yang karakteristiknya hendak diduga. satuan atau individu disebut unit analisis, bisa berupa orang, rumah tangga, tanah, pertanian, dan sebagainya dalam bentuk yang biasa dipakai dalam survei.

Populasi dalam penelitian ini adalah jumlah penduduk di Kotamadya Bogor menurut Badan Pusat Statistik Kota Bogor yaitu berjumlah lebih dari 1.000.000 jiwa.

Sampel menurut Sujarweni (2015) adalah sebagian dari sejumlah karakteristik yang dimiliki oleh populasi yang digunakan untuk penelitian. Bila populasi besar, peneliti tidak mungkin mengambil semua untuk penelitian misal karena terbatasnya dana, tenaga, dan waktu, maka peneliti dapat menggunakan sampel yang diambil dari populasi itu. Apa yang akan dipelajari dari sampel, kesimpulannya akan diberlakukan untuk populasi. Untuk itu, sampel yang diambil dari populasi harus betul-betul mewakili dan harus valid, yaitu bisa mengukur sesuatu yang seharusnya diukur. 
Sampel dalam penelitian ini diambil dengan metode probabilitas, yaitu dengan metode acak sederhana (simple random sampling). Formula dasar dalam penentuan ukuran sampel pada pengambilan sampel probabilitas mengasumsikan bahwa populasi adalah tak terbatas. Jadi sebuah sampel sebanyak 100 (seratus) yang diambil (Sunyoto, 2012).

\section{Teknik Pengambilan Data}

Dalam penelitian ini teknik pengambilan data yang digunakan penulis adalah kuisioner dan dokumentasi. Instrumen yang digunakan untuk mengukur variabel penelitian ini dengan menggunakan skala likert 5 poin. Jawaban responden berupa pilihan alternativ yang ada, yaitu : SS (Sangat Setuju), S (Setuju), N (Netral), TS (Tidak Setuju), STS (Sangat Tidak Setuju). Masing-masing jawaban memiliki nilai sebagai berikut: SS (5), S (4), N (3), TS (2), STS (1).

\section{Metode Analisis Data}

Berdasarkan operasional variabel yakni indikator dari variabel independen dan dependen adalah ordinal maka penelitian ini menggunakan alat analisis data yang akan diolah dengan menggunakan Microsoft Excel 2007 dan SPSS.

Dalam penelitian ini menggunakan teknik analisis deskriptif yaitu statistik yang digunakan untuk menggambarkan berbagai karakteristik data yang berasal dari suatu sampel. Sebelum melakukan analisis tersebut, untuk mendapatkan nilai yang baik, maka perlu melakukan sebuah pengujian pada instrument pengumpul data yang digunakan. Metode pengujian analisis data dalam hal ini adalah validitas dan reabilitas.

\section{Hasil dan Pembahasan}

\section{Gambaran Umum Responden}

Gambaran umum responden penelitian akan diuraikan secara deskriptif dan dibantu dengan penyajian dalam bentuk tabel dari jumlah responden dengan membagi ke dalam beberapa tabel yaitu jenis kelamin dan kelompok usia. Uraian identitas ini diharapkan dapat memberikan gambaran yang cukup jelas tentang kondisi responden dan kaitannya dengan masalah-masalah dan tujuan penelitian.

Tabel 2 Responden berdasarkan jenis kelamin

\begin{tabular}{ccc}
\hline Jenis Kelamin & Frekuensi & Persentase \\
\hline Laki-laki & 0 & $0 \%$ \\
Perempuan & 100 & $100 \%$ \\
Total & 100 orang & $100 \%$ \\
\hline
\end{tabular}

Sumber: data diolah dari responden, Juli 2019

Dari tabel di atas, dapat diketahui bahwa keseluruhan responden yang digunakan adalah perempuan sebesar $100 \%$ dengan jumlah 100 orang

Tabel 3 Responden berdasarkan usia

\begin{tabular}{lll}
\hline Usia & Frekuensi & Presentase \\
\hline
\end{tabular}




\begin{tabular}{ccc}
\hline $18-24$ tahun & 86 & $86 \%$ \\
$25-30$ tahun & 7 & $7 \%$ \\
$>30$ tahun & 7 & $7 \%$ \\
Total & 100 orang & $100 \%$ \\
\hline
\end{tabular}

Sumber: data diolah dari responden, Juli 2019

Dari tabel di atas, dapat diketahui bahwa usia responden terbanyak adalah mereka yang berada pada usia 18-24 tahun yaitu sebanyak 83 responden (83\%), kemudian 25-30 tahun sebanyak 7 responden $(7 \%)$ dan $>30$ tahun tahun sebanyak 7 responden (7\%). Data ini menunjukkan bahwa mayoritas responden adalah yang berada pada usia 18-24 tahun.

\section{Hasil Analisis}

\section{Uji Validitas}

Uji Validitas digunakan untuk mengukur ketetapan suatu item dalam kuesioner atau skala yang ingin diukur. Uji validitas dilakukan dengan membandingkan nilai $r$ hitung dengan nilai $r$ tabel untuk degree of freedom $\mathrm{d}(\mathrm{f})=\mathrm{n}-\mathrm{k}$ dengan alpha 0.05. Jika $\mathrm{r}$ hitung lebih besar dari $r$ tabel dan nilai $r$ positif, maka pertanyaan tersebut dikatakan valid. Untuk hasil analisis dapat dilihat pada output uji reliabilitas pada bagian correted item total correlation. Di dalam penentuan, valid atau tidaknya item digunakan, kegiatan yang harus dilakukan adalah dengan membandingkan rhitung dengan rtabel dimana tarif signifikansi yang digunakan adalah 0,05 dengan $\mathrm{N}=100$ (karena jumlah responden adalah berjumlah 100 orang) maka dapat diperoleh $r$ tabel sebesar 0.195. Untuk mengetahui tingkat validitas tersebut, maka akan dilakukan terlebih dahulu uji statistik dengan menggunakan SPSS 16, adapun hasil outputnya dapat dilihat dari tabel dibawah ini:

Tabel 4 Ringkasan Hasil Uji Validitas Label Halal (X)

\begin{tabular}{cccc}
\hline No & R Hitung & RTabel $(5 \%)$ & Keterangan \\
\hline 1 & 0.571 & 0.195 & Valid \\
2 & 0.872 & 0.195 & Valid \\
3 & 0.898 & 0.195 & Valid \\
4 & 0.539 & 0.195 & Valid \\
5 & 0.571 & 0.195 & Valid \\
6 & 0.711 & 0.195 & Valid \\
7 & 0.872 & 0.195 & Valid \\
8 & 0.780 & 0.195 & Valid \\
9 & 0.728 & 0.195 & Valid \\
10 & 0.898 & 0.195 & Valid \\
\hline
\end{tabular}

Sumber: data diolah dari responden, Juli 2019

Menurut tabel diatas, hasil uji validitas pada variabel X memperlihatkan bahwa nilai $r$ hitung setiap indikator lebih besar dibandingkan dengan nilai dari $r$ tabel yaitu lebih 
besar dari 0.195 . Hal tersebut menunjukkan indikator dari variabel labelisasi halal dan keputusan pembelian dinyatakan valid sebagai alat ukur variabel penelitian.

Tabel 5 Ringkasan Hasil Uji Validitas Keputusan Pembelian (Y)

\begin{tabular}{cccc}
\hline No & R Hitung & RTabel $(5 \%)$ & Keterangan \\
\hline 1 & 0.898 & 0.195 & Valid \\
2 & 0.865 & 0.195 & Valid \\
3 & 0.786 & 0.195 & Valid \\
4 & 0.838 & 0.195 & Valid \\
5 & 0.761 & 0.195 & Valid \\
6 & 0.510 & 0.195 & Valid \\
7 & 0.749 & 0.195 & Valid \\
8 & 0.729 & 0.195 & Valid \\
9 & 0.865 & 0.195 & Valid \\
10 & 0.889 & 0.195 & Valid \\
\hline
\end{tabular}

Sumber: data diolah dari responden, Juli 2019

Menurut tabel diatas, hasil uji validitas pada variabel Y memperlihatkan bahwa nilai $r$ hitung setiapindikator lebih besar dibandingkan dengan nilai dari $r$ tabel yaitu lebih besar dari 0.195 . Hal tersebut menunjukkan indikator dari variabel labelisasi halal dan keputusan pembelian dinyatakan valid sebagai alat ukur variabel penelitian.

\section{Uji Reliabilitas}

Reliabilitas sebenarnya adalah alat untuk mengukur suatu kuesioner yang merupakan indikator dari variabel atau konstruk. Suatu kuesioner dikatakan reliabel atau handal jika jawaban seseorang terhadap pernyataan adalah konsisten, atau stabil. Cara yang digunakan adalah antara lain dengan One shot atau pengukuran sekali saja, yaitu dengan menggunakan uji statistik Cronbach Alpha $(\alpha)$. Suatu variabel dikatakan reliabel jika memberikan nilai Cronbach Alpha $>0.60$. Adapun pengukuran tingkat alpha dilakukan dengan menggunakan program SPSS 16. Adapun hasil dari perhitungannya dapat terlihat pada tabel hasil output SPSS 16 dibawah ini:

Tabel 6 Ringkasan Hasil Uji Reliabilitas

\begin{tabular}{|c|c|c|c|c|}
\hline No & Variabel & $\begin{array}{c}\text { Cronbach } \\
\text { alpa }\end{array}$ & $\begin{array}{c}\text { Cronbach } \\
\text { alpa yang di } \\
\text { isyaratkan }\end{array}$ & Keterangan \\
\hline 1 & Label Halal & 0.909 & $>60 \%$ & Reliabel \\
\hline 2 & Keputusan Pembelian & 0.931 & $>60 \%$ & Reliabel \\
\hline
\end{tabular}

Sumber: data diolah dari responden, Juli 2019

Berdasarkan tabel diatas dapat dilihat bahwa nilai Cronbach Alpha > 60 yaitu $0.909>0.60$ untuk variabel label halal dan $0.931>0.60$ untuk variabel keputusan 
pembelian. maka setiap variabel yang diujikan reliabel atau konsisten,memiliki tingkat reliabilitas yang baik.

\section{Uji Normalitas}

Uji normalitas adalah melakukan perbandingan antara data yang kita miliki dengan data berdistribusi normal yang memiliki mean dan standar deviasi yang sama. Data dikatakan terdistribusi normal jika memenuhi asumsi normalitas data yaitu, data menyebar di sekitar garis diagonal dan mengikuti arah garis diagonal. Jika data menyebar jauh dari garis diagonal, maka model regresi dikatakan tidak memenuhi asumsi normalitas (Ghozali dalam Widodo, 2015:49).

\section{Grafik 1 Ringkasan Hasil Uji Normalitas}

\section{Normal P-P Plot of Regression Standardized Residual}

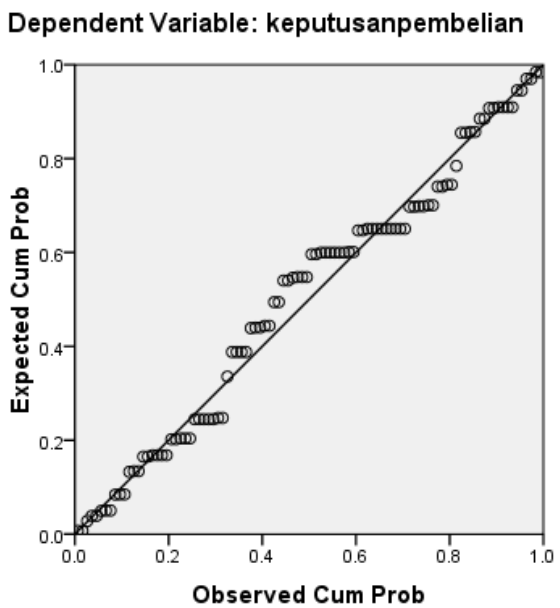

Sumber: data diolah dari responden, Juli 2019

Berdasarkan hasil uji normalitas dengan menggunakan grafik normal probability plot menunjukkan bahwa pola titik-titik pada grafik terlihat menyebar disekitar garis diagonal dan mengikuti arah garis diagonal, sehingga dapat disimpulkan bahwa data berdistribusi normal, maka model regresi yang digunakan dalam penelitian memenuhi asumsi normalitas.

\section{Uji T}

Uji statistik t pada dasarnya menunjukkan seberapa jauh pengaruh satu statistic independen secara individual dalam menerangkan variasi statistik dependen. Berikut ini merupakan statistic hasil uji statistik: 
Tabel 7 Ringkasan Hasil Uji T

\begin{tabular}{|c|c|c|c|c|c|}
\hline \multicolumn{6}{|c|}{ Coefficients $^{a}$} \\
\hline & \multirow{2}{*}{\multicolumn{2}{|c|}{$\begin{array}{c}\text { Unstandardized } \\
\text { Coefficients }\end{array}$}} & \multirow{2}{*}{$\begin{array}{c}\text { Standardized } \\
\text { Coefficients }\end{array}$} & & \\
\hline & & & & & \\
\hline \multicolumn{6}{|c|}{ Std. } \\
\hline Model & $B$ & Error & Beta & $t$ & Sig. \\
\hline i (Constant) & 7.785 & 3.698 & & 2.105 & .038 \\
\hline Labelhalal & .494 & .097 & .459 & 5.110 & .000 \\
\hline \multicolumn{6}{|c|}{ a. Dependent Variable: } \\
\hline \multicolumn{6}{|c|}{ keputusanpembelian } \\
\hline
\end{tabular}

Berdasarkan tabel diatas, dari variabel independen yang dimasukkan kedalam model regresi. Variabel X (Label Halal) berpengaruh secara signifikan terhadap Y (Keputusan Pembelian) hal ini dilihat dari signifikan label halal sebesar 0,000 yang berarti lebih kecil dari tingkat signifikansi yang digunakan yaitu 0,05. Dan dapat juga dilihat dari $\mathrm{t}$ hitung sebesar 5.110 yang berarti $\mathrm{t}$ hitung lebih besar dari $\mathrm{t}$ tabel yaitu 1.984.

Persamaan regresi linier sederhana dalam penelitian ini dapat diformulasikan sebagai berikut:

$$
\begin{aligned}
& \mathrm{Y} \quad=\mathrm{a}+\mathrm{bX} \\
& =\quad 7.785+0.494 \mathrm{X} \\
& \text { Dimana: } \\
& \mathrm{Y} \quad=\text { Keputusan Pembelian } \\
& \mathrm{X} \quad=\text { Label Halal }
\end{aligned}
$$

Berdasarkan persamaan regresi linier sederhana diatas dapat disimpulkan bahwa:

Konstanta sebesar 7.785 yang menyatakan bahwa jika variabel independen dianggap konstan, maka rata-rata keputusan Pembelian mahasiswi sebesar 7.785. Memiliki arti bahwa ketika pembeli membeli produk kecantikan dan tidak terpengaruhi oleh tidak adanya label halal pada kemasan produk, maka keputusan pembelian konsumen sebesar 7.785 .

Koefisien regresi label halal sebesar 0.494 menyatakan bahwa setiap terjadi kenaikan nilai label halal sebesar satu satuan, maka akan diikuti dengan kenaikan keputusan pembelian sebesar 0.494 memiliki arti bahwa ketika ada 1 orang pembeli membeli produk kecantikan dan terpengaruhi atau menyatakan bahwa harus ada label halal pada kemasan produk maka keputusan pembelian konsumen yang terpengaruhi oleh label halal akan bertambah sebanyak 0.494.

\section{Uji R}


Koefisien determinasi (R square atau R kuadrat) atatu disimbolkan dengan "R2" yang bermakna sebagai sumbangan pengaruh yang diberikan variable bebas atau variabel independent $(\mathrm{X})$ terhadap variable teritkat atau variable dependent $(\mathrm{Y})$, atau dengan kata lain, nilai koefisien determinasi atau R square ini berguna untuk memprediksi dan melihat seberapa besar konstribusi pengaruh yang diberikan variable $\mathrm{X}$ terhadap variable $\mathrm{Y}$.

Tabel 8 Ringkasan Hasil Uji R

\begin{tabular}{ccccc}
\hline \multicolumn{5}{c}{ Model Summary $^{b}$} \\
\hline & & & Adjusted $R$ & Std. Error of \\
Model & $R$ & $R$ Square & Square & the Estimate \\
1 & $.763^{a}$ & .583 & .579 & 1.87283 \\
\hline
\end{tabular}

a. Predictors: (Constant), labelhalal

b. Dependent Variable: keputusanpembelian

Sumber: data diolah dari responden, Juli 2019

Berdasarkan table output, diketahui nilai koefisien determinasi atau $\mathrm{R}$ square adalah sebesar 0.583 , nilai $\mathrm{R}$ square 0.583 ini berasal dari pengkuadratan nilai koefisien korelasi atau " $R$ " yaitu yaitu $0.763 \times 0.763=0.583$. Besarnya angka koefisien determinasi ( $\mathrm{R}$ square) adalah 0.583 atau $58.3 \%$. Angka tersebut mengandung arti bahwa variable label halal (X) berpengaruh terhadap variable keputusan pembelian (Y) sebesar 58.3\%.

\section{KESIMPULAN}

Berdasarkan persamaan regresi linier sederhana dapat disimpulkan bahwa konstanta sebesar 7.785 yang menyatakan bahwa jika variabel independen dianggap konstan, maka rata-rata keputusan Pembelian sebesar 7.785. Memiliki arti bahwa ketika pembeli membeli produk kecantikan dan tidak terpengaruhi oleh tidak adanya label halal pada kemasan produk, maka keputusan pembelian konsumen sebesar 7.785. Koefisien regresi label halal sebesar 0.494 menyatakan bahwa setiap terjadi kenaikan nilai label halal sebesar satu satuan, maka akan diikuti dengan kenaikan keputusan pembelian sebesar 0.494 memiliki arti bahwa ketika ada 1 orang pembeli membeli produk kecantikan dan terpengaruhi atau menyatakan bahwa harus ada label halal pada kemasan produk maka keputusan pembelian konsumen yang terpengaruhi oleh label halal akan bertambah sebanyak 0.494 .

Variabel X (Label Halal) berpengaruh secara signifikan terhadap Y (Keputusan Pembelian) hal ini dilihat dari signifikan label halal sebesar 0,000 yang berarti lebih kecil dari tingkat signifikansi yang digunakan yaitu 0,05. Dan dapat juga dilihat dari thitung sebesar 5.110 yang berarti t hitung lebih besar dari t tabel yaitu 1.984. Koefisien regresi label halal sebesar 0.494 menyatakan bahwa setiap terjadi kenaikan nilai label halal sebesar satu satuan, maka akan diikuti dengan kenaikan keputusan pembelian sebesar 0.494 maka dengan demikian Ha diterima, bahwa secara parsial label halal berpengaruh signifikan terhadap keputusan pembelian produk kecantikan. 
Nilai koefisien determinasi atau $\mathrm{R}$ square adalah sebesar 0.583 , nilai $\mathrm{R}$ square 0.583. Besarnya angka koefisien determinasi (R square) adalah 0.583 atau 58.3\%. Angka tersebut mengandung arti bahwa variable label halal (X) berpengaruh terhadap variable keputusan pembelian (Y) sebesar 58.3\%.

\section{REFERENSI}

Badan Pusat Statistik Kota Bogor

Burhan, Artina. 2017. Strategi Penyuluhan Produk Halal Bagi Peserta Diklat Pembina Produk Halal. Jakarta

Eka, Randi. 2018. Lanskap E-commerce di Indonesia dari Perspektif Konsumen https://dailysocial.id/post/e-ecommerce-di-indonesia-2018 (7 April 2019).

Eldine,Achyar.2013. Pengantar BisnisUmum Dan Agri. Penerbit Direktorat Jenderal Perkebunan Kementrian Pertanian: Jakarta

https://id.wikipedia.org/wiki/Majelis_Ulama_Indonesia (7 April 2019)

http://www.halalmui.org (2 Februari 2019)

Kurniawan, Arief Rakhman. 2018. Dasar-Dasar Marketing: Segala Hal Tentang Marketing dan Sales. Penerbit Quadrant: Yogyakarta

Rafita, Helfy Zella. 2015. Pengaruh Label Halal Terhadap Keputusan Pembelian Produk Kosmetik (Studi Pada Mahasiswi Fakultas Ekonomi Dan Bisnis Islam Angkatan 2013-2016 UIN Raden Intan Lampung). Fakultas Ekonomi Dan Bisnis Islam UIN Raden Intan Lampung.

Rozalinda. 2016. Ekonomi Islam: Teori dan Aplikasinya pada Aktifitas Ekonomi. PT RajaGrafindo Persada: Jakarta

Sujarweni, V Wiratna. 2015. Metodologi Penelitian Bisnis dan Ekonomi. Penerbit Pustaka Baru Press: Yogyakarta. 2015.

Press: Yogyakarta

2015. Statistik untuk Bisnis dan Ekonomi. Penerbit Pustaka Baru

Sunyoto, Danang. 2018. Konsep Dasar Riset Pemasaran dan Perilaku Konsumen. Penerbit CAPS (Center for Academic Publishing Service): Yogyakarta..

Tanarto, Harry.2013. Kunci Sukses Sales. Penerbit PT Bhuana Ilmu Populer: Jakarta

Team katadata. 2019. Jumlah Penduduk Indonesia 2019 Mencapai 267 Juta Jiwa. https://databoks.katadata.co.id/datapublish/2019/01/04/jumlahpendudukindone sia-2019-mencapai-267-juta-jiwa diakses (2 Februari 2019.).

Utami, Wahyu Budi. 2013. Pengaruh Label Halal Terhadap Keputusan Membeli. Skripsi: Program Ilmu Komunikasi UIN Sunan Kalijaga: Yogyakarta. 